\title{
CORRECTION
}

View Article Online

View Journal I View Issue

(1) CrossMark

Cite this: J. Mater. Chem. A, 2015, 3, 12558

DOI: 10.1039/c5ta90117k

www.rsc.org/MaterialsA

\section{Correction: Effects of the fabrication process on the grain-boundary resistance in $\mathrm{BaZr}_{0.9} \mathrm{Y}_{0.1} \mathrm{O}_{3-\delta}$}

\author{
S. Ricote, ${ }^{\star a}$ N. Bonanos, ${ }^{b}$ A. Manerbino, ${ }^{c}$ N. P. Sullivan ${ }^{a}$ and W. G. Coors ${ }^{c}$
}

Correction for 'Effects of the fabrication process on the grain-boundary resistance in $\mathrm{BaZr}_{0.9} \mathrm{Y}_{0.1} \mathrm{O}_{3-\delta}$ ' by S. Ricote et al., J. Mater. Chem. A, 2014, 2, 16107-16115.

The conductivity values at $600{ }^{\circ} \mathrm{C}$ of SSR-Ni and SSRS in Table 4 of the manuscript are incorrect. The correct values are included in the revised table below.

Table 4 Conductivity in $\left(\mathrm{mS} \mathrm{cm}^{-1}\right)$ of BZY10 in moist reducing atmosphere at 500 and $600{ }^{\circ} \mathrm{C}$ from this work and literature

\begin{tabular}{|c|c|c|c|c|c|}
\hline Synthesis & Sintering & $\begin{array}{l}\text { Total conductivity } \\
600{ }^{\circ} \mathrm{C}\end{array}$ & $\begin{array}{l}\text { Total conductivity } \\
500{ }^{\circ} \mathrm{C}\end{array}$ & Atmosphere & Ref. \\
\hline Solid state reaction & $5 \mathrm{~h} 1800{ }^{\circ} \mathrm{C}$ & 1.8 & - & $\mathrm{H}_{2}, 1.7 \times 10^{3} \mathrm{~Pa} \mathrm{H}_{2} \mathrm{O}$ & 6 \\
\hline Flash combustion & $1500^{\circ} \mathrm{C}$ & 2.2 & - & $\mathrm{N}_{2}, 3 \% \mathrm{H}_{2} \mathrm{O}$ & 41 \\
\hline Pechini process & $10 \mathrm{~h} 1600^{\circ} \mathrm{C}$ & 0.8 & 0.55 & $\mathrm{~N}_{2}, 20.65 \mathrm{~h} \mathrm{~Pa} \mathrm{H}_{2} \mathrm{O}$ & 42 \\
\hline Solid state reaction & $1700^{\circ} \mathrm{C}$ & - & 0.55 & $5 \% \mathrm{H}_{2}$, moist & 30 \\
\hline $\mathrm{HT}$ & $2200{ }^{\circ} \mathrm{C}$ & 3.43 & 1.7 & $5 \% \mathrm{H}_{2}, 0.03$ atm $\mathrm{H}_{2} \mathrm{O}$ & This work \\
\hline SSR-Ni & $12 \mathrm{~h} 1600^{\circ} \mathrm{C}$ & 2.7 & 1.1 & $5 \% \mathrm{H}_{2}, 0.03$ atm $\mathrm{H}_{2} \mathrm{O}$ & This work \\
\hline SSRS & 5 h $1535^{\circ} \mathrm{C}$ & 3.0 & 1.6 & $5 \% \mathrm{H}_{2}, 0.03$ atm $\mathrm{H}_{2} \mathrm{O}$ & This work \\
\hline
\end{tabular}

The Royal Society of Chemistry apologises for these errors and any consequent inconvenience to authors and readers. 